The Agile City 

JAMES S. RUSSELL

\section{The Agile City}

Building Well-being and Wealth in an Era of Climate Change

Oislandpress

Washington | Covelo | London 


\section{(C) 2011, James S. Russell}

All rights reserved under International and Pan-American Copyright Conventions. No part of this book may be reproduced in any form or by any means without permission in writing from the publisher: Island Press, Suite 300, 1718 Connecticut Ave., NW, Washington, DC 20009

ISLAND PRESS is a trademark of the Center for Resource Economics.

Library of Congress Cataloging-in-Publication Data

Russell, James S.

The agile city : building well-being and wealth in an era of climate change / By James S. Russell.

p. $\mathrm{cm}$.

Includes bibliographical references and index.

ISBN-13: 978-1-59726-724-3 (cloth : alk. paper)

ISBN-10: 1-59726-724-4 (cloth : alk. paper)

ISBN-13: 978-1-59726-725-0 (pbk. : alk. paper)

ISBN-10: 1-59726-725-2 (pbk. : alk. paper)

1. Climatic changes. 2. Climatic changes-Government policy. 3. Economic development. 4. Sustainable development. 5. Financial crises-History-21st century. I. Title.

QC903.R87 2011

363.73874561 dc22

2011005024

Printed on recycled, acid-free paper

Manufactured in the United States of America

$\begin{array}{llllllllll}10 & 9 & 8 & 7 & 6 & 5 & 4 & 3 & 2 & 1\end{array}$

KEYWORDS: Carbon neutrality, climate change adaptation, climate change mitigation, community planning, energy efficiency, environmental design and planning, green architecture, green building, green infrastructure, grey infrastructure, megaburbs, neoburbs, New Orleans rebuilding, sustainable communities, sustainable transportation, water resources 


To Mary and Ralph 



\section{Contents}

Acknowledgments | xi

Prologue: Carbon-neutral Now | xiii

INTRODUCTION:

The Concrete Metropolis in a Dynamic Era | 1

PART 1 The LAND

1 Climate Change in the Landscapes of Speculation | 15

2 A New Land Ethos | 35

Part 2 Repairing the Dysfunctional Growth Machine

3 Real Estate: Financing Agile Growth | 57

4 Re-engineering transportation | 83

5 Ending the Water Wars | 103 
$x$ I CONTENTS

6 Megaburbs: The Unacknowledged

Metropolis | 125

\section{part 3 Agile Urban Futures}

7 Building Adaptive Places | 153

8 Creating Twenty-first-century Community | 177

9 LOOSE-FIt URBANISM | 199

10 Green Grows the Future | 221

Epilogue:

Tools to Build Civic Engagement | 241

Notes | 249

Index | 273 


\section{ACKNOWLEDGMENTS}

Elements of this book gestated over a long time, and many people have been of inestimable help. The late Astra Zarina, who founded the Architecture in Rome program at the University of Washington, introduced me to the ways a great city works. I was able to document the lay of the American urban landscape thanks to insightful editors at Architectural Record: Mildred Schmertz, Stephen Kliment, and Robert Ivy. Manuela Hoelterhoff has been a staunch champion of architecture at Bloomberg. Jeff Weinstein has focused my written vagaries at three different publications.

The New York State Council on the Arts, Bermard Tschumi at Columbia University's Graduate School of Architecture Planning and Preservation, and Sal LaRosa and Ron Bentley have offered welcome financial (and at times moral) support.

It has been a privilege to work with Michael Gallis and benefit from his astounding insights. I have cited many people in the book whose research or experience has enriched the argument, but some I've relied on again and again: Michael Gallis, Christopher Leinberger, Clark Stevens in Montana, Jeanne Nathan and Robert Tannen in New Orleans, Robert Bruegmann in Chicago, and the Lincoln Institute for Land Policy in Cambridge. Thanks also go to Tracy Metz in Amsterdam, David Cohn in Madrid, Peter Slatin, Cathleen McGuigan, Nancy Levinson, Roberta Brandes Gratz, Kenneth Frampton, Amanda Burden, Barry Bergdoll, and Ada Louise Huxtable. At Island Press, heartfelt thanks to editor Heather Boyer and to Courtney Lix and Rebecca Bright.

I could not have gotten this book done without Robert Hughes, Hillary Brown, S. J. Rozan, Monty Freeman, Amy Schatz, and Max Rudin. I am the lucky beneficiary of unflagging love, support, and inspiration from Steven Blier. 



\section{Prologue}

\section{Carbon-neutral Now}

The blond stone walls and handsome vaulted roof of Kroon Hall have an unassuming barnlike presence amid neo-Gothic neighbors at Yale University. An intimate plaza, a pleasing meeting place for the School of Forestry and Environmental Studies, welcomes you. Hefty wooden louvers on the tall, narrow entrance side cut afternoon sun (figure P.1). Inside, sun filters down the woodpaneled main stair, inviting you to climb to the top-floor reading room, with its gracefully vaulting ceiling. There, photovoltaic panels over skylights shower celestial light, perfectly balanced by stripes of sunlight seeping through the louvered end wall. You might notice the little green and red lights next to the windows that signal when natural breezes can be used instead of heating and cooling, but you probably do not know that five very-low-energy systems heat and cool the building. It's not obvious that Kroon's long narrow shape minimizes absorption of summer heat while gathering the low winter sun and grabbing passing breezes for ventilation. Though the building fits as comfortably as an old pair of jeans, Hopkins Architects, of London, working with the locally based Centerbrook Architects and Planners, have calibrated every detail of this new office and seminar-room building to produce, husband, or harvest energy (figure P.2).

A few years ago, a building could garner headlines because it cut energy use 20 or 30 percent from today's norms. Kroon aimed much higher, at "carbon neutrality": reducing to zero the heat-trapping gases that warm the planet. ${ }^{1}$

Zero. A few years ago, experts would have said you can't get there. But improvements in building design, technology, and construction now make carbon-neutral buildings an increasingly reachable goal. Electric cars can be 


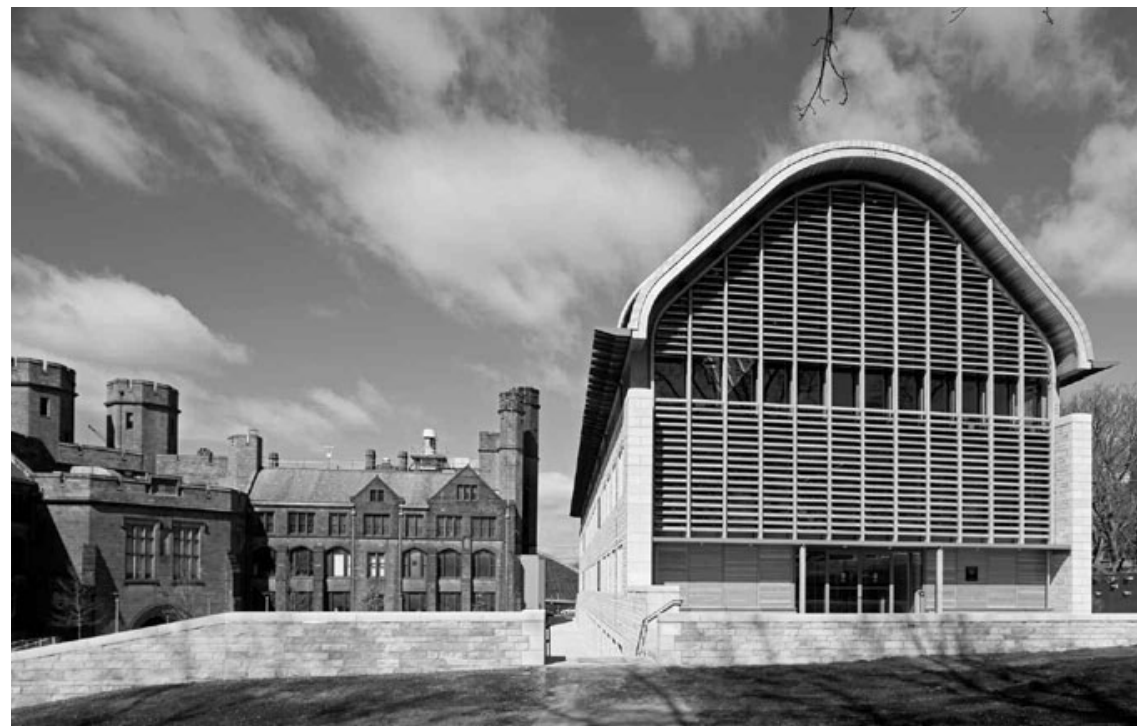

Figure P.1 Kroon Hall, Yale University. The louvers on the east-facing side of this building are one of many tactics designed by Hopkins Architects with Centerbrook Architects to achieve near zero-carbon emissions. Credit: (C) Robert Benson

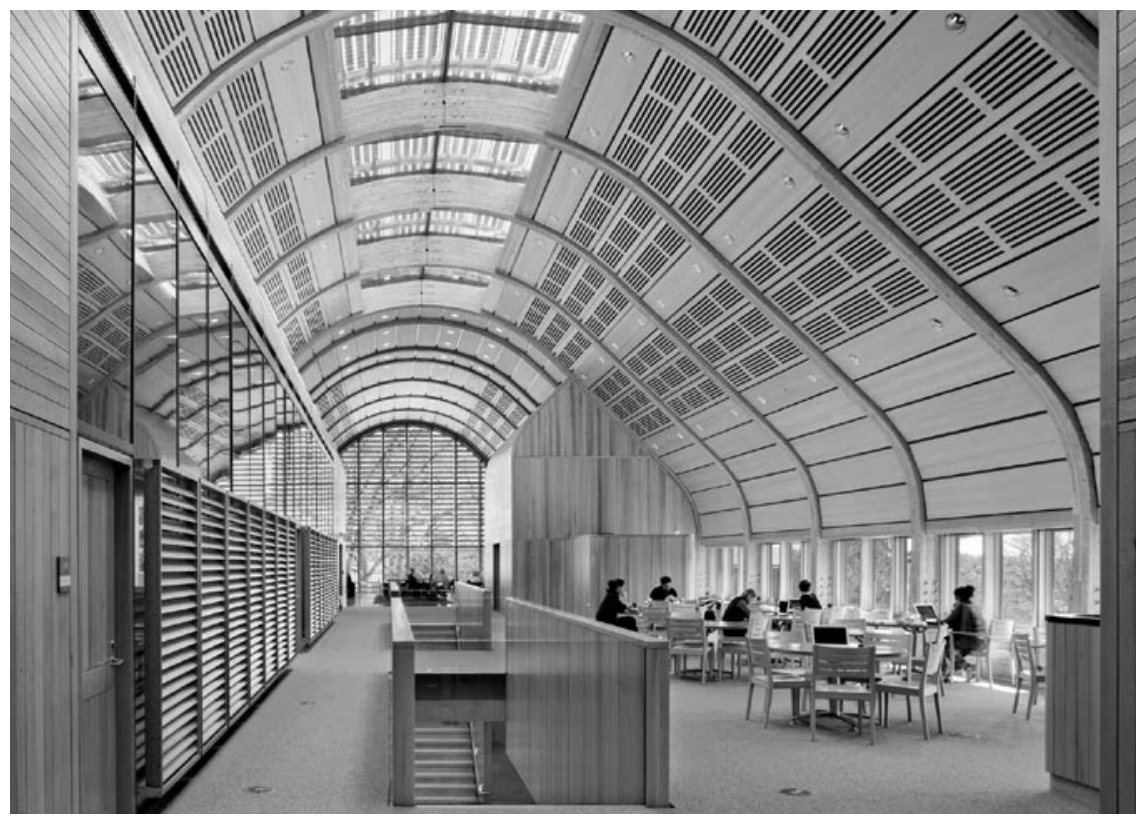

Figure P.2 The daylighted top-floor reading room and café at Kroon Hall, Yale University. Photovoltaic panels over skylights generate energy and filter the sun, which balances sidelight seeping through the building's protective exterior louvers. Credit: (c) Robert Benson 
considered zero emission only if the power that charges them comes from relatively rare renewable sources. Workable zero-emission coal-fired power plants and zero-emission gas-driven ones look far away in time.

As global warming effects become more evident, and the debate over what to do about it becomes more difficult, it's important to know that buildings can get to zero. After all, they are responsible for almost 40 percent of US greenhouse gas emissions.

A geothermal well system draws heat from the earth in winter and cools in the summer. A displacement-ventilation system relies on the buoyancy of warm air to ventilate the building with only minimal fan use. These devices cost more, and are unusual but not exotic. "The only way to make really efficient buildings is to employ as many different strategies as possible," Hopkins's director, Michael Taylor, says. "We reduced energy demand by 50 percent, and then met 25 percent of the energy needs with a 100-kilowatt photovoltaic array, so we have a resulting 62.5 percent reduction in our carbon footprint." This isn't zero but comprises the state of the carbon-reduction art at this writing.

Pull the focus out to the scale of communities, though, and you can see how much more can be accomplished.

At the western edge of North America, on the southern tip of the mountainous and densely forested Vancouver Island, Dockside Green has already become carbon positive. The mix of town houses, mid-rise apartments, and commercial buildings is rising in phases on a narrow, fifteen-acre former industrial site just above the famous Inner Harbor of Victoria, British Columbia (figure P.3).

Dockside Green harnesses economies of scale to affordably build in carbon-reduction measures that are impractical for single buildings. From an apartment rooftop, where owners tend rows of lettuce, you can look down on a stream, planted with native wetland grasses, that burbles in front of the outdoor terraces of town houses (figure P.4). The stream is clean enough that crayfish thrive and ducks nest even though it mixes runoff from rain-harvesting gardens and water treated in an on-site sewage plant. Vancouver architecture firm Busby Perkins + Will (master planner of the site) designed the first eight buildings to cross ventilate and to capture warmth from the low winter sun, as Kroon does. Awnings automatically unfurl to cut unwanted heat. These tactics, with 100 percent fresh-air mechanical ventilation, make the elimination of air-conditioning possible in Victoria's temperate climate. Meters in each apartment provide real-time information on water use, heating bills, and elec- 


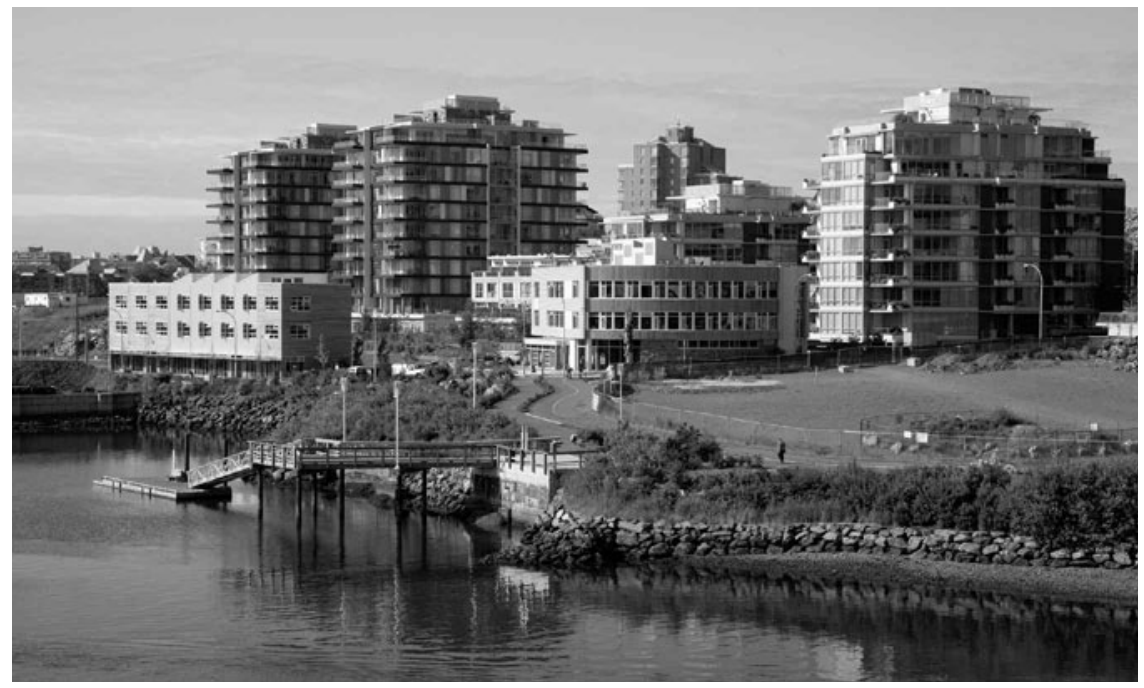

Figure P.3 Overview of the early phases of Dockside Green, in Victoria, British Columbia. Its location near downtown allows residents to get to destinations along a bike path that runs along the Inner Harbor and on a passenger ferry that crosses it. Credit: Courtesy Dockside Green

trical use. The flickering data mesmerize owners, who scamper about, snuffing phantom kilowatts. With familiar devices, such as compact-fluorescent lighting and Energy Star appliances, Dockside Green cuts its energy use by more than 50 percent below Canada's building-code standards.

As the project got under way, Joe Van Belleghem, a partner at Windmill West (Dockside Green's codeveloper, with Vancity, a credit union), got plenty of local attention when he promised to write the city a $\$ 1$ million check if any of the buildings fell below Platinum-level certification (the highest tier) of the LEED (Leadership in Energy and Environmental Design) green-building rating system. So far, he has not had to pay up. Dockside Green will eventually include twenty-six buildings and be home to about twenty-five hundred people in three neighborhoods. At that scale, the developers were able to afford to build a biomass gasification plant, which accelerates the decomposition of construction-waste wood into a clean-burning biogas that supplies hot water and hydronic heating to the entire development. Van Belleghem collects fees from residents for the heat and hot water he provides, which will largely pay for the plant's construction. By producing its own heating fuel and supplying the excess output to an adjacent hotel, according to architect Peter Busby, 


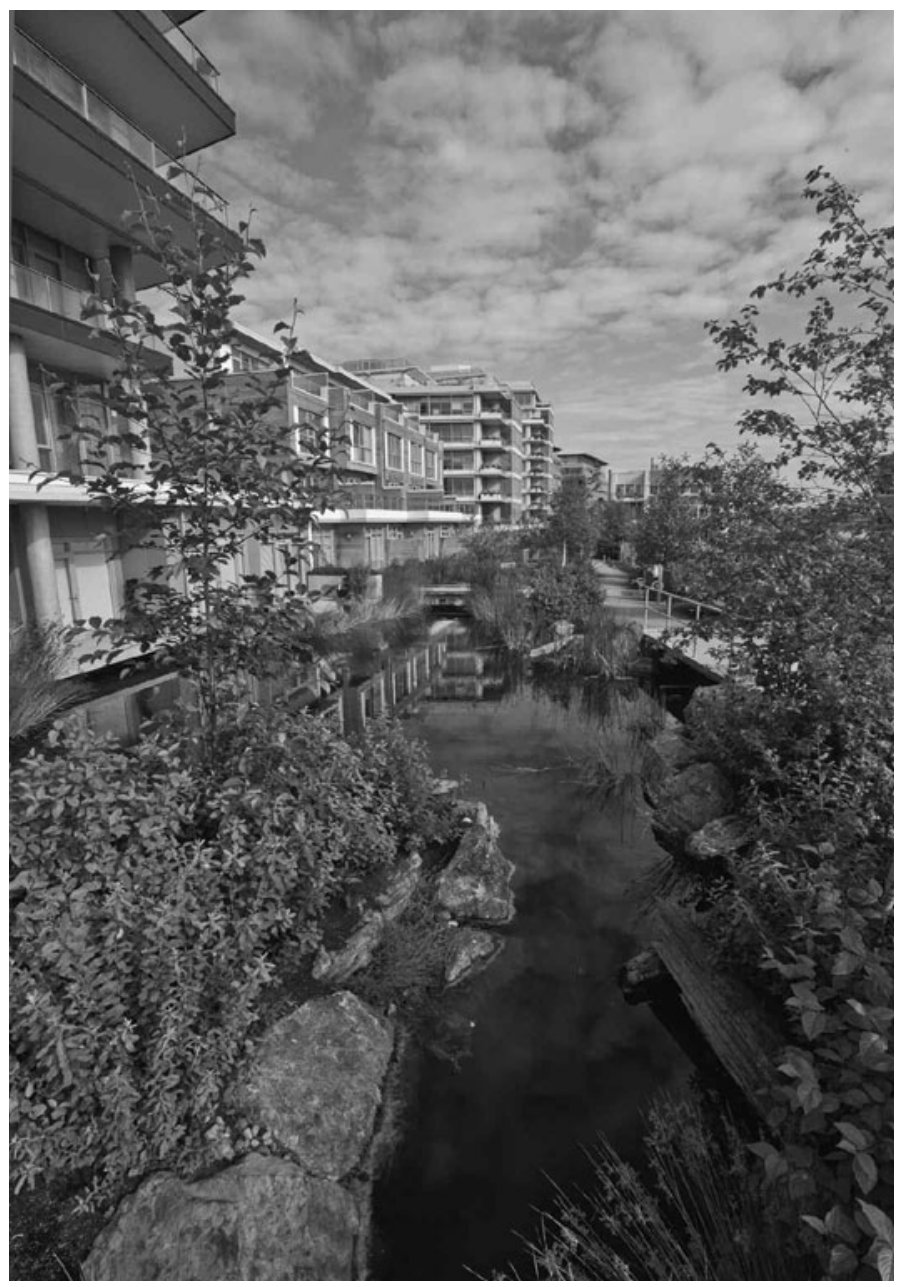

Figure P.4 At Dockside Green, storm runoff and water treated in an on-site sewage plant combine in a naturalized stream that creates an amenity for residents as it keeps polluted water out of Victoria's sparkling Inner Harbor. Credit: Courtesy Dockside Green

Dockside Green makes up for the carbon content of the electricity it needs from the grid to power lights and appliances. That's how it is carbon positive.

Dockside Green goes a step further by helping to reduce auto dependency, which saves more energy and reduces the carbon footprint of everyday activities. Its location links residents to four bus lines, a tiny passenger ferry-cute 
as a toy-that chugs to various locations around the bay, and the Galloping Goose bike path, which has become a commuting artery. The developer also subsidizes membership in a local car cooperative. "We encourage you to become a member and get in the habit of not using your own car," Van Belleghem says. The developer will pay $\$ 25,000$ to buy back the parking space built for each unit. ${ }^{2}$

Kroon and Dockside are both pioneering and quotidian. They use advanced but proven technologies. Neither is noticeably an "eco building," ostentatiously showing off solar panels, nor do they demand lifestyle changes (through Dockside makes biking to work easy). Both the building and the community are more appealing and functional than conventional versions.

In the total absence of a coherent American approach to climate change, both Kroon and Dockside Green go deeply green, showing how quickly such strategies are progressing. If you want to achieve carbon neutrality today, even the most efficient designs must augment with solar, wind, biofuel, or hydropower, and these sources demand special conditions (a breeze, a dammed stream nearby) or a considerable amount of space (solar), and usually cost much more per square foot than conservation measures do (as was the case at Kroon). Indeed, Yale balked at the cost and land area needed to fully meet Kroon's energy needs on-site. (It purchased carbon credits to get to zero.) Had the university chosen to build a district power plant that used renewable fuel, as Dockside Green does, Yale would not have needed to purchase the credits, and it would have reduced the carbon footprint of any building hooked onto the system.

Most buildings and settings cannot yet cost-effectively lower their energy and carbon impact to such a great degree. You begin to see that the barriers are not overwhelming, however. The Agile City is about how buildings and communities help the United States rapidly close its yawning green performance gap while making places that work better and realize our dreams. 